\begin{tabular}{|c|c|}
\hline 1. 1.54 & Malaysian Journal of Social Sciences and Humanities (MJSSH) \\
\hline $\begin{array}{c}\text { Malaysian Journal of } \\
\text { solal sciences and }\end{array}$ & Volume 5, Issue 9, September 2020 \\
\hline (MJ-SSH) & e-ISSN : 2504-8562 \\
\hline & $\begin{array}{l}\text { Journal home page: } \\
\text { www.msocialsciences.com }\end{array}$ \\
\hline
\end{tabular}

\title{
Faktor Penghalang Poligami: Kajian Kes Ke Atas Guru-Guru Lelaki di Daerah Kinabatangan, Sabah
}

\author{
Saifulazry Mokhtar¹, Mohd Zaidi Mustafa1, Kasoma Thia1, Mohd Maziz al-Hadi Moharam¹, \\ Habibah Artini Ramlie ${ }^{1}$ \\ 1Pusat Penataran Ilmu dan Bahasa, Universiti Malaysia Sabah (UMS)
}

Correspondence: Saifulazry Mokhtar (saifulazry.mokhtar@ums.edu.my)

\begin{abstract}
Abstrak
Poligami merupakan syariat Islam yang sering disalah ertikan oleh masyarakat. Ini menyebabkan poligami semakin menjadi dagang dalam kalangan umat Islam, bahkan mereka yang terlibat dengan poligami dipalit dengan pelbagai tuduhan liar yang menggambarkan kebuasan nafsu, kezaliman kepada wanita, penderaan mental kepada anak-anak, punca keruntuhan rumahtangga, pengamalan sihir dan sebagainya. Kajian ini dijalankan bertujuan untuk melihat pandangan guru-guru lelaki di daerah Kinabatangan, Sabah terhadap amalan berpoligami serta mengenal pasti faktor penghalang dalam mengaplikasi poligami dalam kehidupan. Seramai 64 orang guru lelaki yang dipilih berdasarkan kemampuan, minat dan pandangan kritikal kepada poligami serta kesediaan mereka untuk memberikan kerjasama sepenuhnya. Kajian ini telah menggunakan kaedah kualitatif dengan memfokus kepada temubual dengan responden dipilih. Dapatan kajian menunjukkan terdapat dua faktor utama yang menjadi penghalang kepada guru-guru lelaki di daerah Kinabatagan untuk melaksanakan poligami iaitu faktor dalaman dan faktor luaran. Faktor dalaman lebih mendominasi guru-guru lelaki berbanding faktor luaran. Bagi merealisasikan hasrat poligami ini, pelbagai pihak perlu memainkan peranan dalam meyakinkan lelaki khususnya untuk berpoligami agar ia diterima baik oleh masyarakat.
\end{abstract}

Kata kunci: poligami, guru lelaki, faktor dalaman dan luaran

\section{Factors that Prevents Polygamy: A Case Study on Male teachers in the District of Kinabatangan, Sabah}

\begin{abstract}
Polygamy in Islam often misunderstood by many. This resulted in the proliferation of polygamy among Muslims, and that those practices polygamy generally being accused of depicting savagery, cruelty to women, mental abuse to children, the cause of the collapse of the household, the practice of magic and so on. This study looks at the views of male teachers in the district of Kinabatangan, Sabah on the practice of polygamy as well as to identify barriers to polygamy in their social life. A total of 64 male teachers were selected based on their ability, interest and critical views over polygamy as well as their willingness to provide full cooperation. This study applies qualitative methods which focuses on interviews with selected individuals. The findings of the study show that there are two main factors that hinder male teachers in Kinabatagan to practice polygamy, namely internal factors and external factors. It suggests that the internal factors impacted male teachers significantly as compared to external factors. Thus, it portrays that to realize this desire for
\end{abstract}


polygamy, various parties need to play a role in convincing men to practice polygamy which acknowledged by the society.

Keywords: polygamy, male teacher, internal and external factors

\section{Pengenalan}

Poligami dari sudut bahasa adalam menghimpunkan berbilang isteri dalam satu masa. Mengikut Kamus Dewan (2010), poligami bererti amalan beristeri lebih daripada seorang pada masa yang sama. Dalam bahasa Arab, poligami disebut $t a^{c}$ addad al-Zawjat. Asal perkataan $t a^{c} a d d a d$ bererti bilangan, manakala perkataan al-Zawjat bererti isteri. Kedua-dua perkataan tersebut apabila digabungkan membawa erti isteri yang banyak atau berbilang-bilang. Menurut Zaini Nasohah (2000), poligami boleh dimaksudkan sbagai berkahwin lebih daripada seorang iaitu lawan kepada perkataan monogami yang membawa erti berkahwin dengan seorang wanita sahaja. Pada dasarnya poligami yang disarankan oleh Allah SWT adalah sangat istimewa sepertimana yang termaktub dalam barisan ayat al-Quran dan Hadis.

Namun, kebanyakkan poligami yang muncul kini tersasar dari landasan Islam yang sebenar tanpa mengikut acuan Islam yang disyariatkan. Selain itu terdapat juga pandangan-pandangan serta penerimaan yang negatif daripada golongan wanita terhadap poligami. Sesetengah masyarakat juga keliruan dalam memahami selok belok poligami secara mendalam. Ini kerana poligami yang bercampur aduk diantara hukum yang syariatkan dengan peraturan mahkamah syariah hari ini menyebabkan berlakunya poligami yang tidak sejajar dengan kehendak Islam. Persepsi buruk yang ditanam oleh musuh Islam telah menjadi barah dalam kalangan masyarakat Islam sehingga masyarakat Islam mula meragui ayat-ayat Allah dan amalan para nabi serta para salafus soleh yang mensyariatkan poligami untuk menyelamatkan umat daripada kehancuran. Golongan wanita menjadi golongan yang paling lantang menentang syariat ini sedangkan pensyariatan poligami adalah untuk membela wanita sebagai golongan yang perlu dilindungi (Surah al-Nisa' 4:3).

Golongan lelaki yang ditugaskan melindungi wanita sepatutnya bersedia memikul amanah berpoligami bagi menjaga ummah ini dengan penuh dedikasi dan pertanggungjawaban. Namun demikian, mereka melihat amanah ini hanya sebagai tahsiniyyat atau hanya untuk lelaki yang hebat sahaja sehingga sanggup dilabelkan sebagai lelaki yang lemah dan menerima seadanya. Ini bertentangan dengan peranan lelaki sepertimana yang Allah rakamkan dalam al-Quran (Surah al-Nisa' 4:34). Lebih malang lagi, poligami hanya menjadi bualan mainan yang meniti dibibir-bibir lelaki atau usikan untuk mengganggu wanita. Namun dari segi realitinya, lelaki atau perempuan tidak bersedia untuk memikul tanggungjawab berumahtangga melalui kaedah poligami dengan pelbagai persepsi negatif yang mengekang terlaksananya poligami dalam kehidupan umat Islam hari ini.

Aplikasi whatsap, telegram dan facebook sentiasa menjadikan gambar atau kisah poligami viral dalam aplikasi tersebut. Apa yang menghairankan, kadar mereka yang mengamalkan poligami terlalu sedikit. Tidak berpatutan dengan sambutan dan perbualan hangat dalam kalangan masyarakat kita hari ini. Menurut Ketua Perangkaan Malaysia, Penduduk Sabah seramai 3.9 juta yang melibatkan 2.0 juta atau $51.28 \%$ lelaki dan 1.9 juta atau $48.72 \%$ wanita. Daripada jumlah ini, hanya $0.0003 .6 \%$ sahaja yang berpoligami. Begitu juga negeri Perlis yang mempunyai penduduk seramai 0.25 juta orang, hanya 0.002 \% sahaja yang berpoligami sekalipun negeri Perlis terkenal dengan negeri yang memudahkan urusan untuk berpoligami. Apakah sindrom yang menghantui umat Islam sehingga syariat yang cukup mulia ini tidak dipraktikkan dalam kehidupan masyarakat kita?

Lantaran itu, artikel ini meninjau minat golongan guru-guru lelaki di daerah Kinabatangan untuk berpoligami dan mengesan kesungguhan kesediaan mereka untuk berpoligami. Ini kerana dari segi hakikatnya nisbah yang berpoligami terlalu sedikit. Akan tetapi, dimana sahaja ada mereka yang sudah berumahtangga yang berbicara soal kebajikan, soal masalah keruntuhan akhlak anak-anak muda, soal ibu tunggal, soal wanita yang lewat berkahwin, soal kemandulan dan sebagainya pasti jawapannya terarah menerusi kehidupan berpoligami. Pandangan ini bukan hanya dilontarkan oleh masyarakat 
marhain, bahkan turut dilontar oleh para cendikiawan melalui pelbagai media, bahkan kisah poligami para artis, tokoh politik, pemandu lori, guru pencen dan sebagainya menjadi tajuk penting dan menjadi bualan dalam kalangan masyarakat kita.

\section{Kajian Literatur}

Bagi merealisasikan kajian kes ini, pengkaji telah merujuk kepada beberapa kajian dan artikel yang telah dijalankan sebelum ini. Dalam kajian yang dijalankan oleh Farrah Wahida Mustafar dan Adam Badrulhisham (2018) adalah untuk mengkaji persepsi para isteri dalam Ikhwan Polygamy Club (Kelab Poligami Ikhwan (KPI)) dan Club Taat Suami dari Kelab Ikat Suami Global Ikhwan Sdn. Bhd. (GISB) terhadap poligami. Hasil kajian tersebut menadapati poligami difahami sebagai suatu keperluan dan kepentingan bagi pengikut GISB dengan mengembalikan segala-galanya kepada tuhan. Malah mereka menganggap poligami sebagai jalan untuk lebih dekat dengan tuhan. Kajian ini juga mendapati GISB lebih bersifat patriarki kerana melebihkan kaum lelaki dengan kurang menitikberatkan soal emosi isteri. Ini kerana mereka menganggap poligami sebagai suatu bentuk dakwah dan keperitan dalam hidup berpoligami sebagai penghapus dosa. Selain itu, pengkaji juga mendapati GISB menekankan peranan poligami sebagai mendekatkan diri kepada tuhan. Boleh dirumuskan bahawa tahap keyakinan mereka terhadap mursyid dan guru cukup tinggi sehingga berpegang teguh dengan kosep poligami sebagai satu bentuk ujian yang perlu dihadapi oleh para isteri.

Bagi kajian Siti Zubaidah Ramli, Hana Duerama dan Farrah Wahida Mustafar (2018) melihat pandangan mazhab Syafie dalam kaedah pembahagian nafkah menerusi keluarga yang mengamalkan poligami. Dapatan kajian beliau menemui bentuk nafkah dalam keluarga poligami terbahagi kepada tiga corak iaitu bentuk nafkah yang dibantu oleh suami, nafkah keluarga dari pendapatan isteri sahaja dan nafkah keluarga dari kedua-dua pihak iaitu suami dan isteri. Walau bagaimanapun, kurangnya komunikasi berkaitan hak dan nafkah tersebut antara suami isteri boleh menjejaskan hubungan perkahwinan ini dan secara tidak langsung memberi kesan yang tidak baik dalam institusi kekeluargaan. Secara kesimpulannya, terdapat suami yang berpoligami namun tidak menjalankan tanggungjawabnya dengan baik kerana tidak memberikan nafkah dan tidak berkomunikasi dengan baik dengan ahli keluarga selari dengan tuntutan syarak khususnya dalam mazhab Syafi'i.

Manakala Zulfikri Hassan (2012) pula berkonsepkan persepsi staf wanita terhadap amalan poligami serta mengetahui sejauh mana mereka bersetuju dengan amalan poligami tersebut. Selain itu tujuan kajian beliau juga tertumpu kepada faktor-faktor yang mempengaruhi persepsi mereka terhadap poligami. Hasil kajian tersebut menemui tiga tema penerimaan yang mencatatkan kekerapan tertinggi dengan skor $88.8 \%$ iaitu aspek pegangan agama dan berilmu, kemampuan dari segi ekonomi, zahir dan batin serta aspek keadilan. Bagi tema suami yang lalai terhadap tuntutan syariat Islam, bersikap negatif dalam kehidupan mencatatkan kekerapan penolakan tertinggi iaitu $88.8 \%$ diikuti dengan dorongan nafsu sebanyak $77.7 \%$ dan masing-masing $44.4 \%$ bagi tema peranan suasana sekeliling serta pengaruh media dan situasi isteri yang kecewa dengan sikap suami.

Menurut kajian Muhammad Syafiq Imran Shamsuddin (2018) lebih melihat kepada ketidakseragaman prosedur poligami di Malaysia. Beliau meneliti bagaimana prosedur poligami di antara Wilayah Persekutuan dan negeri Terengganu serta tinjauan hukum Islam terhadap perbezaan prosedur poligami yang ada di Wilayah Persekutuan dan negeri Terengganu. Manakala kajian Ahmad Zamri Ramidi (2014) pula berkisar tentang kepentingan memahami pengertian dan konsep poligami yang sebenar agar tidak terpengaruh dengan golongan yang tidak memami konsep poligami sebenar. Beliau juga turut menjelaskan peruntukkan Undang undang melalui kuasa mahkamah dan Undang-Undang Kekeluargaan Islam (UUKI) telah digubal untuk mengawal poligami daripada disalah ertikan oleh masyarakat serta tersasar dari kehendak Islam. Selain itu, beliau juga berusaha untuk memperbaiki tanggapan serong dari golongan wanita, masyarakat dan umat Islam khasnya terhadap kehidupan berpoligami.

Kajian Dasuki Ahmad (1975) membincangkan tentang poligami sebelum Islam, hikmat poligami, serta poligami Nabi Muhammad SAW. Beliau tidak membincangkan permasalahan-permasalahan masa kini. Perbincangan hanya terbatas kepada poligami dalam Islam sahaja sedangkan tidak menyebut poligami 
yang dibentuk oleh undang-undang sivil. Ini berbeza pula dengan kajian yang dijalankan oleh Rafiah Yusof (2008), dimana kajian beliau membincangkan keupayaan poligami dalam menyelesaikan masalah ummah masa kini dan membuat beberapa cadangan untuk menjadikan poligami itu sejahtera. Tulisan Ummu Sofwah (2009) pula membongkar pengalaman 30 tahun pengkaji berpoligami ini ada turut menyentuh tentang suatu tafsiran yang salah tentang poligami tetapi masih tidak menjawab permasalah sebenar kekangan-kekangan menjadi persepsi masyarakat sehingga membantu perkembangan poligami.

Kajian berkaitan poligami zaman Rasulullah SAW juga tidak ketinggalan dikaji dan diketengahkan oleh sarjana masa kini. Kajian Musfir al-Jahrani (2004) membincangkan tentang sejarah poligami, syaratsyarat poligami serta hikmat-hikmat poligami Rasulullah. Perbincangan hanya berkisar di zaman Rasulullah sahaja. Bagi Ali Yasir (1983) pula memaparkan tentang motif poligami rasulullah SAW dan isteri-isteri baginda. Beliau menyingkap berbagai hikmah perkahwinan bainda dengan isteri-isterinya. Aidil Akhyar (2014) mengetengahkan hakikat rumahtangga anbiya, rumahtangga teladan Rasulullah, Salafus Soleh dan menjelaskan poligami yang bersesuaian dengan syariat dengan memberi penekanan dari segi keadilan terhadap ahli keluarga disamping memaparkan kisah poligami nabi Daud dan Rasulullah SAW. Buku ini juga tidak membincangan masalah yang dikaji pengkaji iaitu yang berkaitan dengan persepsi dan kekangan untuk berpoligami.

Manakala kajian Asmak Haji Ali (2006) membincangkan secara ringkas sikap remaja mengikut peringkat umur dan bagaimana remaja boleh mudah terjebak ke arah salah laku sosial. Faktor utama yang disebutnya ialah daripada institusi keluarga yang pincang. Beliau juga turut mendedahkan kajian beliau yang menunjukkan remaja terjebak dalam salah laku sosial $63.6 \%$ kerana pengaruh kawan, $48 \%$ suka mencuba, 37.6\% kerana release tension, 19.4\% pengaruh media dan $19 \%$ untuk mendapat perhatian. Di akhir kertas kerjanya, beliau mencadangkan beberapa cadangan yang bernas namun tidak menyebut mengenai peranan poligami sebagai salah satu usaha membendung masalah sosial apatah lagi persoalan kekangan poligami.

Kajian literatur terakhir adalah kajian Hafiz Firdaus Abdullah (2012) yang membincangkan hikmah, hukum dan keadilan dalam poligami, syarat-syarat poligami, larangan-larangan poligami, tips poligami untuk suami, tips poligami untuk isteri sedia ada, tips poligami untuk isteri baharu dan isteri-isteri yang lain. Keseluruhannya, segala keperluan hal ehwal poligami dibincangkan dengan teliti. Malah pengkaji e-book ini berpendapat bahawa subjek poligami hendaklah diberi perhatian yang sungguh-sungguh sepertimana subjek-subjek keagamaan yang lain. Janganlah kita menjadi seumpama orang-orang yang beriman kepada hukum yang disukai sementara ingkar kepada hukum yang mereka anggap berat, tidak menguntungkan atau zalim.

\section{Metodologi Kajian}

Bagi melengkapkan dapatan kajian pengkaji mengaplikasikan kaedah kuantitatif iaitu borang kaji selidik dan kaedah kuantitatif iaitu temu bual dan pemerhatian. Sebagaimana saranan penyelidik terdahulu seperti Ahmad Tarmizi, Romzi \& Nurul (2017), Ationg (2017), Ationg, Guiness, Ibrahim, Esa, Rahman, Hiew\& Tung Moi (2020) dan Ationg \& Guiness (2020), pengkaji menyediakan set borang kaji selidik untuk dibahagi kepada guru-guru lelaki yang berkhidmat di Kementerian Pelajaran Malaysia di Kinabatangan. Pengkaji juga menemubual beberapa orang pengamal poligami, isteri, bujangan secara langsung atau tidak langsung mengenai kekangan poligami. Temu bual juga akan diadakan terhadap tokoh-tokoh yang dianggap ahli dan berpengalaman dalam bidang berkaitan bagi mendapatkan data kajian yang terkini yang tidak terkandung dalam bahan bacaan. Seterusnya pengkaji juga akan menggunakan metode pemerhatian ini semasa mengumpul data. Melalui metode ini, pengkaji akan membuat pengamatan terhadap masyarakat yang terdapat di sekitar sasaran kajian.

\section{Hasil Kajian}

Faktor Penghalang Poligami Kepada Guru Lelaki di Daerah Kinabatangan 
DOI: https://doi.org/10.47405/mjssh.v5i9.487

Berdasarkan dapatan hasil soal selidik dan temu bual yang dijalankan, pengkaji menemui dua faktor utama yang menjadi penghalang kepada pelaksanaan amalan poligami bagi guru-guru lelaki di daerah Kinabatangan, Sabah. Dua faktor tersebut adalah faktor dalaman dan faktor luaran. Berikut adalah perincian dan huraian bagi kedua-dua faktor tersebut.

\section{Faktor Dalaman}

Faktor dalaman yang dimaksudkan dalam kajian ini adalah faktor dalaman yang ada dalam diri setiap guru lelaki. Faktor dalaman ini merupakan faktor utama kepada penghalang untuk menjadikan poligami sebagai satu amalan dalam kehidupan. Dalam kajian ini pengkaji telah berjaya menemui lima faktor dalaman yang mempengaruhi pemikiran guru-guru lelaki di daerah Kinabatangan dari terlaksananya syariat sunnah nabi dalam konteks poligami. Berikut adalah kupasan kelima-lima faktor tersebut.

\section{a) Masalah Kekangan Kewangan, Bebanan Hutang dan Tahap Kesihatan}

Masalah kewangan juga turut memainkan peranan yang menjadi penghalang untuk berpoligami. Sekalipun mempunyai gaji bulanan para responden bergelut dengan masalah kewangan dan terikat dengan hutang. Berdasarkan kepada Rajah 1, majoriti responden masih keliru sama ada sumber kewangan menjadi faktor penyebab kepada penolakan amalan poligami. Ini kerana seramai 28 orang atau $43.75 \%$ responden memberi jawapan tidak pasti dengan kenyataan mereka mampu membiaya kewangan untuk memikul tanggungjawab isteri baharu dan anak-anak mereka kelak. Hanya seramai 23 orang atau 35.94\% sahaja responden yang mengjustifikasikan dirinya bersetuju dengan persoalan yang diajukan. Manakala bilangan responden yang tidak bersetuju dengan penyataan yang diberikan adalah seramai 13 orang iaitu $20.31 \%$.

Rajah 1: Kemampuan membiaya kewangan dan memikul tanggungjawab

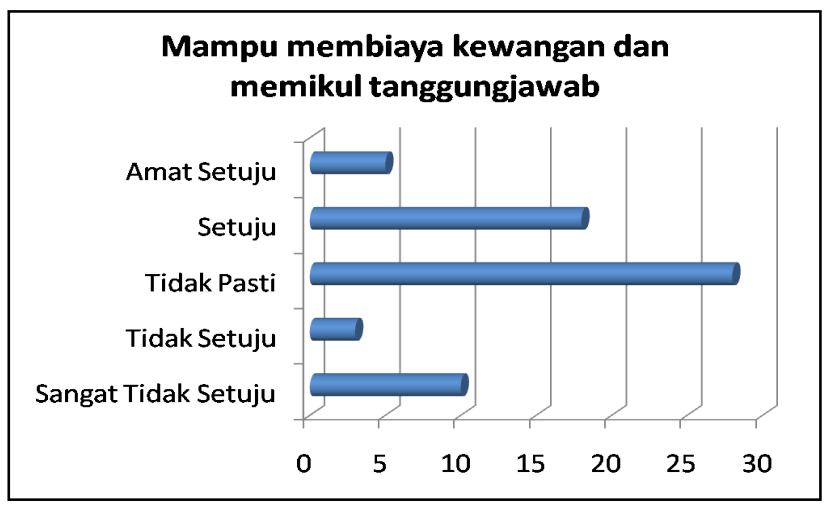

Bagi persoalan bebanan hutang pula dapatan kajian adalah seperti Rajah 2. Berdasarkan Rajah 2 tersebut, majoriti responden tidak mempunyai bebanan hutang yang kritikal.

Rajah 2: Hutang

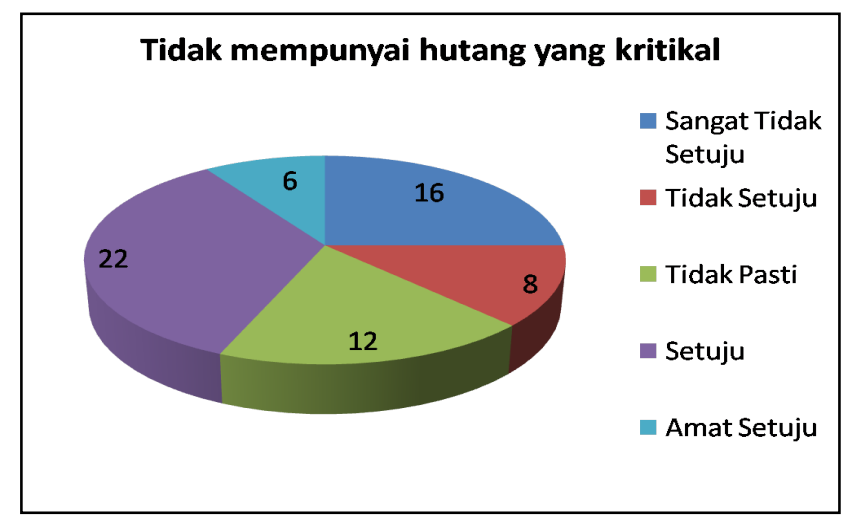


Ini kerana seramai 28 orang responden atau $43.75 \%$ bersetuju dengan persoalan yang diajukan kepadanya. Daripada jumlah tersebut seramai 24 orang atau $37.5 \%$ responden yang menghadapi masalah kewangan yang kritikal dan ia sekaligus menjadi faktor kapada penghalang keinginan mereka untuk berpoligami. Hanya seramai 12 orang atau $18.75 \%$ responden yang tidak pasti sama ada penyataan ini menjadi faktor penghalang poligami ataupun tidak.

Dari segi tahap kesihatan pula, guru-guru lelaki di daerah Kinabatangan adalah cukup sihat dan bersedia untuk memikul tanggungjawab menjaga isteri, anak-anak sedia ada serta anak-anak yang akan datang. Berdasarkan kepada Rajah 3 diatas, seramai 44 orang responden atau $68.75 \%$ mempunyai tahap kesihatan yang baik, cergas serta dapat melaksanakan tanggungjawab dengan sempurna. Walau bagaimanapun terdapat seramai 14 orang responden atau $21.87 \%$ yang tidak pasti dengan tahap kesihatan mereka sama ada mampu atau tidak memikul tanggungjawab tersebut. Hanya seramai 6 orang atau 9.38\% yang tidak mempunyai tahap kesihatan yang baik serta menafikan bahawa mereka tidak bersedia untuk memikul tanggungjawab lain sedangkan tanggungjawab sedia ada pun belum tentu dapat dijalankan sebaik-baiknya.

Rajah 3: Tahap Kesihatan

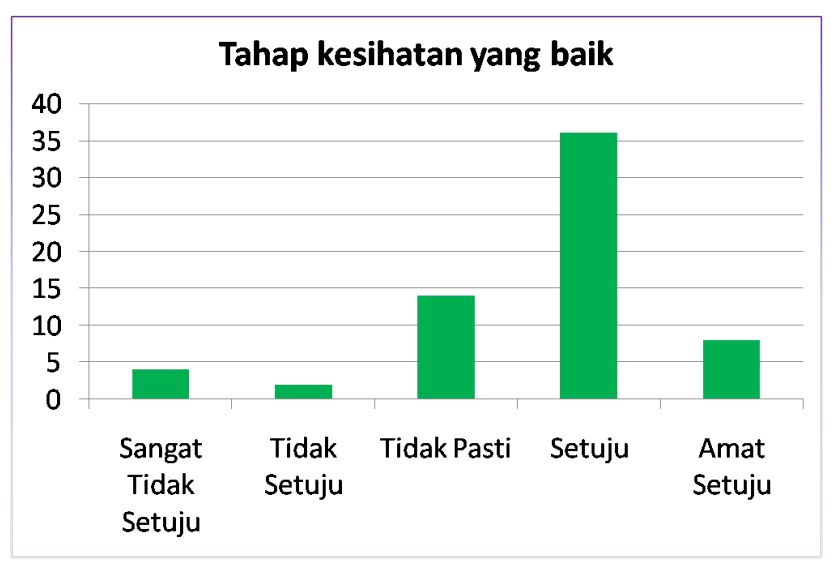

\section{b) Kebimbangan untuk Meminang dan Memenuhi Keperluan Perkahwinan}

Rajah 4 adalah hasil dapatan kajian berteraskan kebimbangan responden untuk meminang dan memenuhi keperluan perkahwinan. Dapatan menunjukkan responden kajian ini cukup yakin pada diri. Mungkin kerana mereka sudah berkerjaya dan mempunyai kewangan yang kukuh disamping kedudukan yang tinggi di mata masyarakat. Kesanggupan untuk meminang isteri untuk dipoligami menunjukkan $52.56 \%$ atau 33 orang yang bersedia. Hanya $29.69 \%$ sahaja yang memilih tidak pasti ataupun teragakagak untuk menampilkan keberanian meminang pasangan seterusnya dan memenuhi keperluan perkahwinan baharu ini. Manakala seramai 12 orang atau $18.75 \%$ responden yang tidak bersedia untuk masuk meminang dan memenuhi keperluan perkahwinan.

Rajah 4: Persediaan meminang dan memenuhi keperluan perkahwinan

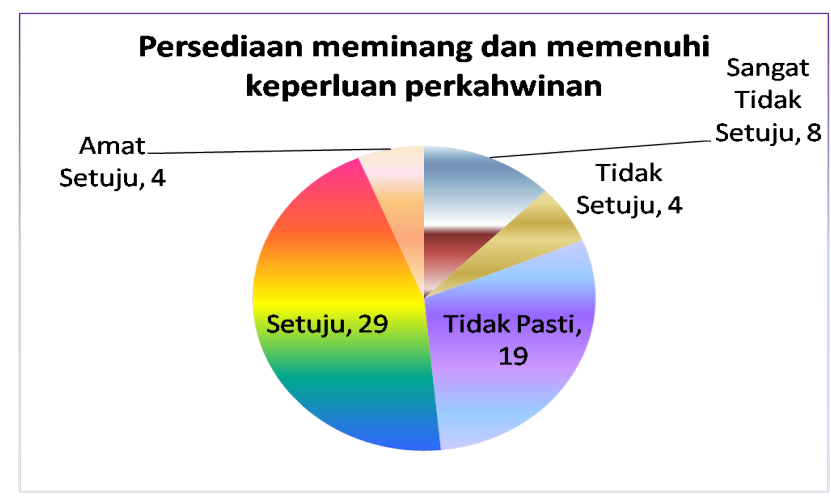




\section{c) Ketidaksediaaan dicop lelaki gatal dan kehilangan kawan}

Pandangan masyarakat umum yang mencemuh poligami turut menjadi faktor halangan kepada masyarakat memilih hidup berpoligami. Berdasarkan Rajah 5, tekanan, umpatan dan cemuhan masyarakat termasuk rakan sekerja dan sahabat handai menunjukkan $45.3 \%$ responden tidak bersedia menghadapi cabaran ini. Hanya seramai 19 orang atau $29.69 \%$ sahaja yang menyatakan kesediaan atau mengambil sikap tidak peduli atas cemuhan dan umpatan masyarakat. Bahkan 16 orang atau 25\% menyatakan mereka tidak kisah kawan baik sekalipun mengelak untuk berkawan dengan mereka dan dicop sebagai lelaki gatal. Namun demikian, 35.9\% responden tetap takut dan terkesan dengan tohmohan ini termasuk $37.5 \%$ yang tidak pasti kebimbangan mereka terhadap risiko cemuhan dan hilang kawan.

Rajah 5: Pandangan masyarakat

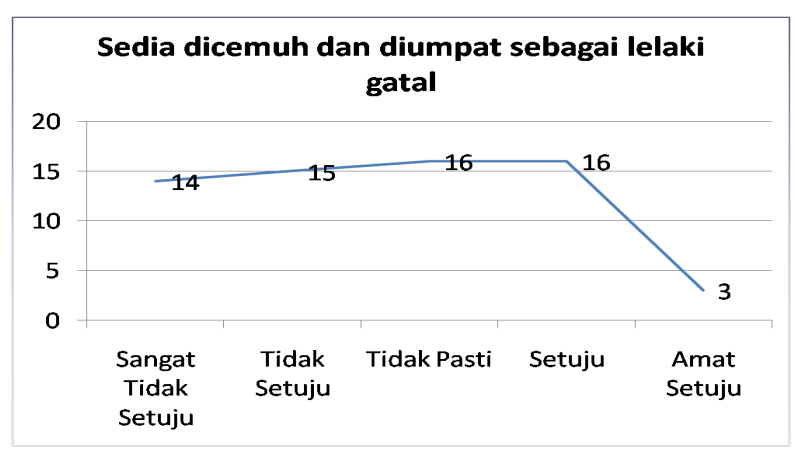

\section{d) Kesediaan memiliki dan menjaga anak tiri}

Rajah 6 menunjukkan hasil dapatan bagi kesediaan suami memiliki dan menjaga anak tiri sekiranya dia berpoligami. Kajian ini mendapati kesediaan memikul tanggungjawab bukanlah halangan untuk berpoligami. Para responden menunjukkan kesediaan untuk tambahan tanggungjawab menyara keluarga baharu termasuk anak tiri dari isteri baharu sekiranya berkahwin dengan janda yang sudah memiliki anak. Dapatan kajian menunjukkan seramai 39 orang atau $60.94 \%$ responden setuju dan bersedia memiliki anak tiri. Manakala seramai 13 orang responden atau $20.31 \%$ tidak pasti bersedia atau tidak dan seramai 12 orang atau $18.75 \%$ responden yang tidak bersedia untuk menerima dan menjaga anak tiri.

Rajah 6: Kesediaan memiliki dan menjaga anak tiri

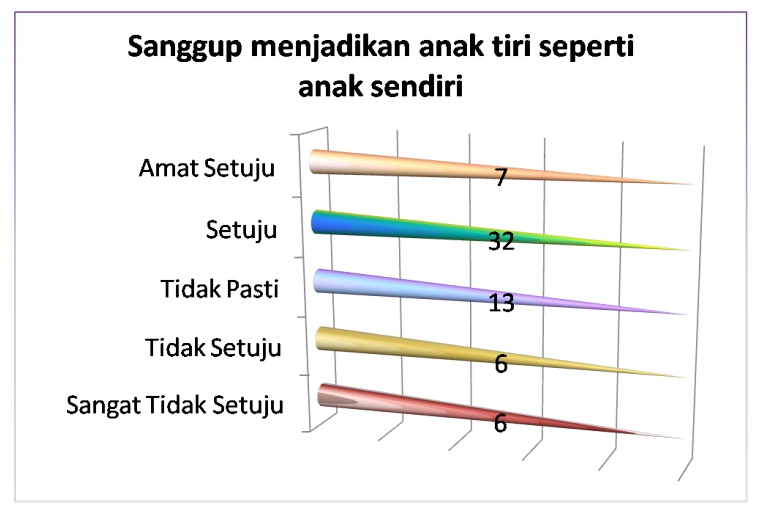

\section{e) Ketidaksanggupan mengurus kebajikan isteri dan anak-anak kecil}

Sekalipun statistik menunjukkan kesediaan berpoligami dalam kalangan responden rendah tetapi mereka menunjukkan keyakinan tinggi sekiranya berpoligami mereka sanggup berhadapan dengan cabaran 
baharu dalam rumahtangga yang baharu. Berdasarkan Rajah 7, seramai 42 orang atau $65.63 \%$ responden menyatakan kesediaan untuk mengurus kehamilan isteri baharu termasuk menjaga kandungan, bangun malam untuk menukar lampin bayi, mencuci kain lampin dan sebagainya. $21.88 \%$ atau seramai 14 orang yang ragu-ragu dengan kesangguapan ini dan hanya $12.5 \%$ atau seramai 8 orang sahaja yang nyata tidak sanggup untuk kembali menjalankan amalan rutin yang telah ditinggalkan. Mungkin juga faktor umur dan kekuatan badan. Selain itu, responden turut bersedia menghadapi kerenah isteri baharu dan isteri sedia ada yang pasti tidak sunyi dari cemburu, dengki dan kuat menuntut hak masing-masing. Tidak kurang juga kebimbangan berdepan dengan merua-mertua, ipar duai dan anak-anak tiri.

Rajah 7: Kesanggupan Menunaikan Tanggungjawab Sebagai Suami

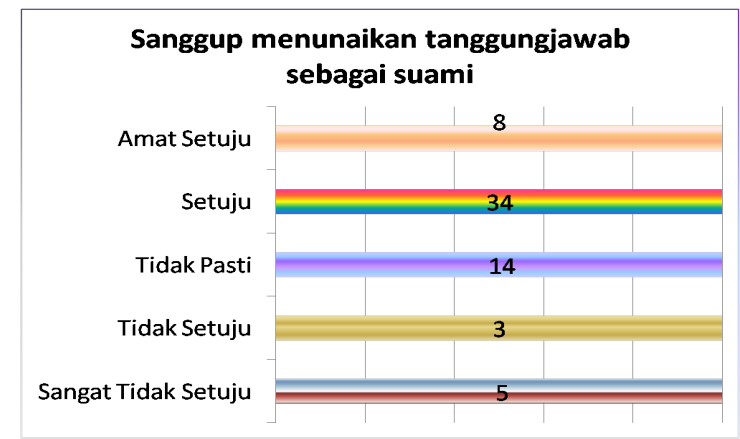

\section{Faktor Luaran}

Kajian ini turut menemui beberapa faktor luaran yang telah menjadi banteng dan penghalang kepada amalan poligami dalam kalangan guru-guru lelaki di daerah Kinabatangan. Terdapat tiga faktor luaran yang dikaitkan dengan penghalang poligami iaitu tentangan daripada isteri, tentangan daripada keluarga dan anak-anak serta kebimbingan tindakan tatatertib daripada majikan dan urusan mahkamah syariah.

\section{a) Tentangan daripada Isteri}

Tentangan daripada isteri dilihat sebagai faktor terbesar dalam faktor luaran yang menghalang poligami. Semasa sesi temubual lisan pun ada yang menyebabkan isteri beremosi bahkan ada yang mencemuh kajian ini. Berdasarkan Rajah 8, seramai 34 orang atau 53.13\% isteri responden memberikan jawapan yang negatif dan tidak bersetuju jika suaminya mengamalkan poligami atau berkahwin lagi. Ini kerana tidak ada satu jawapan yang kukuh untuk suaminya berkahwin lagi dengan kebahagiaan yang telah dikecapi selama ini. Walau bagaimanapun seramai 21 orang atau $32.81 \%$ responden yang tidak pasti sama ada isterinya bersetuju atau pun tidak untuk dia berkahwin lagi. Ini kerana mereka tidak terlintas untuk bertanya kepada isterinya hal poligami sperti ini. Namun terdapat seramai 9 orang atau $14.06 \%$ responden yang mengatakan bahawa isterinya bersetuju jika suaminya berkahwin lagi dan mereka rela untuk dimadukan. Temubual lisan juga mendapati ada isteri responden yang mogok lapar apabila mendapati suaminya ingin berpoligami. Ancaman ini mungkin menyebabkan respon memilih untuk meminta persetujuan isteri sekiranya mereka ingin berpoligami dan hanya sebilangan kecil sahaja responden yang menolak untuk meminta izin isteri kerana memahami risiko yang bakal mereka hadapi.

Rajah 8: Persetujuan Isteri

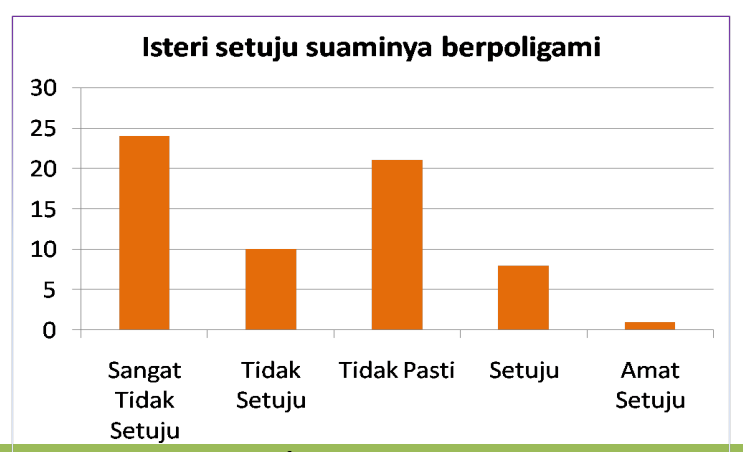


DOI: https://doi.org/10.47405/mjssh.v5i9.487

\section{b) Tentangan daripada keluarga dan anak-anak}

Bukan mudah untuk menghadapi keluarga isteri dan keluarga sendiri jika berpoligami. Bermacam tekanan yang akan diterima oleh mereka yang berpoligami. Ini kerana $76.56 \%$ latar belakang keluarga sama ada disebelah responden atau isteri mereka tidak berpoligami. Poligami tetap asing dalam keluarga sekalipun $23.44 \%$ dari keluarga mereka mempunyai ahli keluarga yang terdiri daripada bapa ataupun adik beradik yang telah mengamalkan poligami. Berdasarkan Rajah 9, seramai 32 orang atau 50\% responden tidak pasti pandangan ibubapa mereka sekalipun 28 orang atau $43.75 \%$ dari ibubapa mereka yang menunjukkan penentangan dan hanya seramai 4 orang atau $6.25 \%$ yang bersetuju.

Rajah 9: Galakkan Ibu Bapa untuk Berpoligami

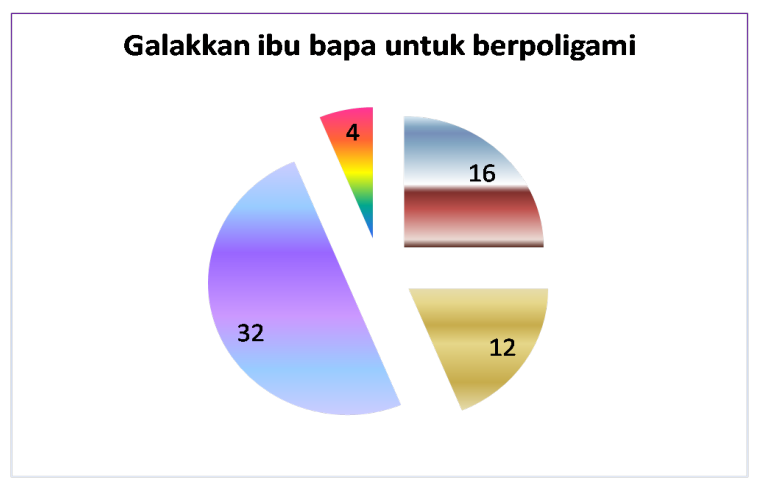

Manakala Rajah 10 pula adalah dapatan kajian pandangan anak-anak terhadap bapanya berpoligami. Berdasarkan Rajah 10 di aatas, responden menyakin seramai 19 orang atau 29.69\% anak-anak mereka akan menentang hasrat mereka untuk berpoligami dan seramai 36 orang atau $56.25 \%$ tidak pasti sambutan anak-anak mereka kepada usaha murni. Akan tetapi, halangan daripada anak-anak tidaklah sebesar halangan daripada ibu mereka. Walau bagaimanapun terdapat seramai 9 orang responden atau $14.06 \%$ yang mengatakan anak-anak mereka akan menyokong bapanya untuk berpoligami. Daripada statistik ini juga menunjukkan bahawa responden lelaki tidak berbincang atau tidak pernah menyatakan keinginan untuk berpoligami kepada ibubapa dan keluarga mereka. Begitu juga di dalam keluarga sendiri, bapa jarang berbincang dengan anak-anak tentang poligami. Tidak pasti adalah jawapan paling tepat menunjukkan interaksi dan pendidikan bapa terhadap anak-anak berkaitan poligami ini rendah.

\section{Rajah 10: Pandangan Anak-anak Terhadap Berpoligami}

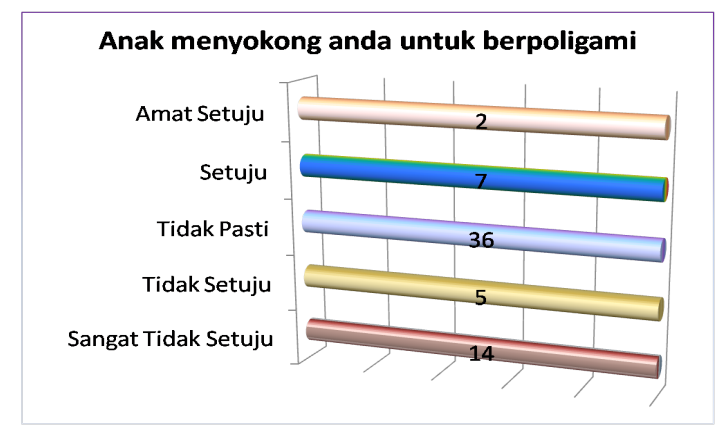

\section{c) Kebimbangan Tindakan Tatatertib daripada Majikan dan Urusan Mahkamah Syariah}

Faktor luaran ketiga yang menghalang guru-guru lelaki di daerah Kinabatangan untuk berpoligami adalah kebimbingan tindakan tatatertib daripada majikan dan urusan mahkamah syariah. Dalam Seksyen 23(1) Akta Undang-undang Keluarga Islam Wilayah Persekutuan telah memperuntukkan bahawa seseorang lelaki yang mahu berkahwin lain perlu untuk memohon keizinan daripada Mahkamah Syariah terlebih dahulu. Sekiranya dia berkahwin tanpa kebenaran maka perkahwinan tersebut tidak boleh 
didaftarkan, maka kahkamah akan memanggil isteri sedia ada supaya hadir untuk member keterangan mengenai perkara yang ditimbulkan oleh suami di dalam borang permohonan untuk berpoligami di Mahkamah Syariah. Sebagai penjawat awam, mereka terikat dan mesti mematuhi undangan-undang Negara dan undang-undang kekeluargaan Islam. Berdasarkan Rajah 11 di bawah, seramai 25 orang atau $39.06 \%$ responden mengatakan bahawa undang-undang untuk berpoligami di Sabah adalah ketat dan menyusahkan. Sebanyak 21 orang atau $32.81 \%$ responden tidak pasti dengan ketetapan Undang-undang Keluarga Islam dalam hal poligami manakala seramai 18 orang atau $28.13 \%$ responden tidak bersetuju mengatakan undang-undang untuk berpoligami di Sabah itu ketat dan susah. Ini kerana, sekiranya seseorang yang ingin berpoligami itu perlulah mengikut prosedur yang telah ditetapkan oleh pihak Jabatan Hal Ehwal Agama Islam Negeri Sabah (JHEAINS). Sekiranya prosedur tersebut dapat diikut dengan baik, nescaya proses poligami akan berjalan lancar seperti yang direncanakan.

Rajah 11: Undang-undang Poligami

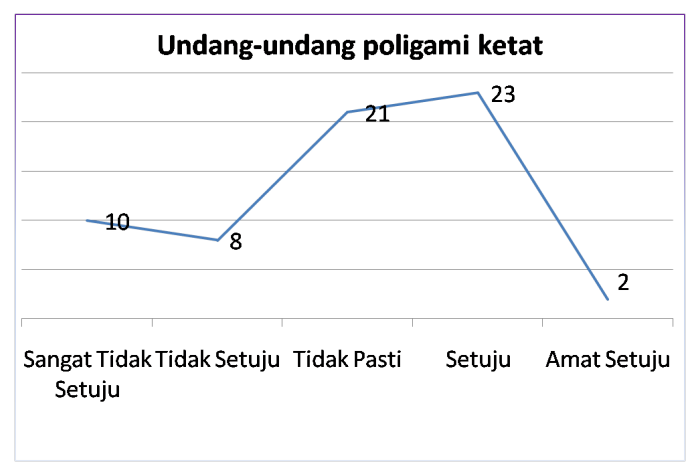

Permohonan untuk berpoligami mesti dilakukan mengikut tempat dimana majlis akad nikah itu akan berlangsung. Permohonan untuk berpoligami hendaklah disertai dengan suatu akuan yang mengatakan alasan-alasan mengapa perkahwinan yang dicadangkan itu dikatakan patut dan perlu, pendapatan pemohon pada masa itu, butir-butir komitmennya, kewajipan dan tanggungan kewangannya termasuk orang yang akan menjadi tanggungannya berikutan dengan perkahwinan yang dicadangkan itu. Namun demikian, apabila diajukan soalan sama ada bersedia atau tidak untuk berulang alik ke mahkamah syariah, dapatan kajian adalah seperti Rajah 12 di bawah.

Rajah 12: Urusan Mahkamah

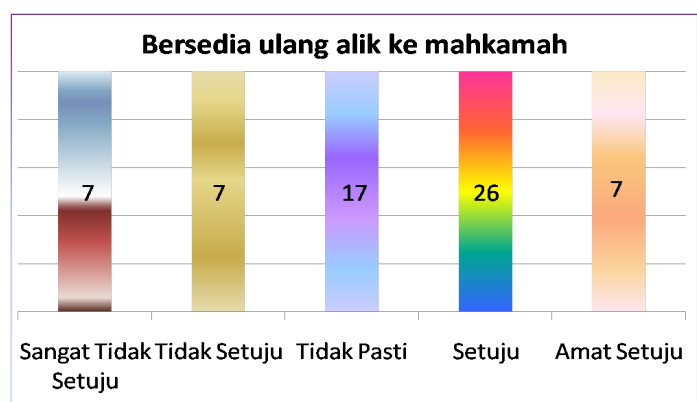

Seramai 33 orang atau $51.56 \%$ responden bersedia ulang alik ke mahkamah bagi menguruskan perkahwinan baharu mereka. Seramai 17 orang atau $26.56 \%$ yakin pasti untuk mendaftarkan perkahwinan mereka bagi menjadikan perkahwinan mereka itu legal dan para isteri mempunyai hak yang jelas. Hanya 14 orang atau $21.88 \%$ yang tidak bersedia untuk ulang alik ke mahkamah syariah serta tidak memberi kerjasama dengan pihak JHEAINS dalam urusan poligami dan akan menyembunyikan perkahwinan mereka disebabkan halangan-halangan tertentu. Walau bagaimanapun seramai 22 orang atau $34.36 \%$ responden tidak bimbang tindakan tatatertib dikenakan kepada mereka demi kelangsungan hasrat mereka untuk berpoligami. Akan tetapi $37.5 \%$ atau bersamaan 24 orang responden tidak pasti dan $28.14 \%$ atau seramai 18 orang yang takut tindakan tatatertib yang akan menjejaskan kerjaya dan periuk nasi mereka. 


\section{Kesimpulan}

Daripada hasil kajian yang dibuat, di dapati faktor halangan dan ketidakyakinan lelaki paling dominan menjadi penyebab kepada terhalangnya hasrat untuk berpoligami. Terlalu banyak pertimbangan yang dibuat oleh lelaki sehingga ia menjadi halangan yang besar. Perasaan kasihan kepada isteri, malu berdepan dengan keluarga bakal isteri, keluarga isteri sedia ada dan keluarga sendiri antara faktor dalam yang lelaki hadapi. Malah pada diri lelaki terdapat serba serbi kekurangan yang membantut hasrat dan cita-cita untuk berpoligami. Kekangan kewangan, kesihatan, komunikasi, tindakan tatatertib, tanggungjawab untuk berlaku adil dan bebanan semasa poligami terus memberatkan pemikiran lelaki untuk berpoligami. Lantaran itulah, apabila diajukan persoalan wanita yang menjadi pilihan kiranya berpoligami, mereka memilih wanita yang serba sempurna dengan rupa, harta, pangkat dan kedudukan sehingga menjadikan ia semakin rumit. Faktor masyarakat sekeliling seperti rakan sekerja, jiran tetanga, keluarga terdekat dan masyarakt umum turut menyumbang terhalangnya poligami. Sikap dan persepsi negatif masyarakat yang prejudis dan memulau memberi kesan yang cukup besar. Kebanyakkan responden tidak bersedia dicemuh, diumpat dan dilabelkan dengan label-label negatif. Selain itu, mereka juga takut kehilangan rakan baik kerana akan ada sahabat yang mengelak dipalit label yang sama sehingga ke tahap tidak dibenarkan bertamu. Halangan-halangan ini boleh dirungkai dengan keimanan dan kecintaan kepada Allah. selagimana manusia memilih dan mengutamakan dunia selagi itulah polekmik ini tidak akan selesai. Serangan pemikiran yang dilakukan oleh barat yang menggerakkan perjuangan hak asasi wanita terutama poligami telah Berjaya selepas kejatuhan empayar Islam. Umat Islam mesti mengembalikan Islam di tempatnya sesuai dengan Islam sebagai cara hidup.

\section{Rujukan}

Ahmad Tarmizi Abdul Rahman, Romzi Ationg and Nurul Ain Zulhaimi. (2017). A paradigm shift in understanding mixed method research: A Malaysian perspective. Journal of Advanced Research in Social and Behavioural Science, 9(1), 46-56.

Aidil Akhyar, Dr. (2014). Sunnah Poligami Generasi Awal Islam. Kuala Lumpur: Pustaka Azahar.

Asmak Haji Ali. (2006). Salah Laku Remaja Masa Kini, Cabaran Dan Penyelesaian, Universiti Teknologi MARA.

Ationg, R. (2017). Federal political leaders and the expansion of ethnic politics to the periphery state of Sabah in Malaysia. PhD Thesis, Australian National University, Canberra, Australia.

Ationg, R. Guiness, P., Ibrahim, M.A., Esa, M.S., Rahman, S.A., Hiew, W. \& Tung Moi, C. (2020). Federal Politicians and the Expansion of Ethnic Politics through Demographic Character Change in Sabah. TEST: Engineering and Management, 83, 12726 - 12740.

Ationg, R. \& Guiness, P. (2020). The Transferability of Ethnic Politics: A Theoretical Perspective. TEST: Engineering and Management, 83, 12741 - 12755.

Bryden, J.M. (2000). Structural Changes in Rural Europe. University of Aberdeen

Dasuki Ahmad, Haji. (1975). Poligami Dalam Islam. Universiti Teknologi Malaysia. Skudai.

Dewan Bahasa dan Pustaka (2010). Kamus Dewan. Petaling Jaya: Dewan Bahasa dan Pustaka.

Farrah Wahida Mustafar dan Adam Badrulhisham. (2018). Konsep Poligami Mengikut Perspektif Para Isteri dalam Jemaah Global Ikhwan Sdn. Bhd. Jurnal Maw'izah, 1, 65 - 88.

Hafiz Firdaus Abdullah. (2012). 202 Pelajaran Berkenaan Poligami. Johor : Perniagaan Jahabersa.

Muhammad Syafiq Imran Shamsuddin. (2018). Prosidur Poligami Di Malaysia. Universitas Islam Negeri ar-Raniry Darul Salam, Aceh.

Musfir al-Jahrani (2004). Mengapa Rasulullah S.a.w Beristeri Ramai. Kuala Lumpur: Terbitan Cresent News (KL) Sdn.Bhd.

Rafiah Yusof. (2008). Poligami Dalam Islam : Merungkai Beberapa Masalah Sosial Hari Ini. Disertasi Sarjana Pengajian Islam. Fakulti Pengajian Islam. Universiti Kebangsaan Malaysia. Bangi.

Siti Zubaidah Ramli, Hana Duerama dan Farrah Wahida Mustafar. (2018). Realiti Keluarga Poligami: Komunikasi Nafkah Menurut Perspektif Mazhab Syafi'i. Jurnal 'Ulwan, 1, 146-159.

Ummu Sofwah. (2009). Indahnya Poligami. Selangor: One Art Production.

Zaini Nasohah. (2000). Poligami Hak Istimewa menurut Syariat Islam. Kuala Lumpur: Percetakan Cergas (M) Sdn.Bhd. 
Malaysian Journal of Social Sciences and Humanities (MJSSH), Volume 5, Issue 9, (page 137 - 148), 2020

DOI: https://doi.org/10.47405/mjssh.v5i9.487

Zulfikri Hassan. (2012). Satu Tinjauan dalam Kalangan Wanita Berkahwin dan Bekerja di Universiti Teknologi Malaysia Terhadap Amalan Poligami. Disertasi Sarjana Pendidikan Fakulti Pendidikan, Universiti Teknologi Malaysia. 